\title{
Принципы формирования туристско-рекреационных кластеров на особо охраняемых природных территориях в Арктической зоне
}

\author{
Е.Ю.Прокофьева, МАРХИ, Москва \\ А.В.Лабезная, МАРХИ, Москва
}

Статья посвящена проблеме формирования туристскорекреационных кластеров (ТРК) на особо охраняемых природных территориях (00ПТ) в Арктической зоне Российской Федерации (АЗРФ).

Вопросы выявления особенностей взаимодействия туристической деятельности в северных регионах на 00Пт недостаточно разработаны, что на практике может привести к утрате ценных природных элементов, а также к деградации городов и поселений, находящихся непосредственно в зоне влияния природного окружения. Каждое новое созданное пространство на природной территории оставляет экологический след, и благодаря непрерывно развивающемуся обществу происходит постоянное преобразование существующих природных структур, что часто приводит к деградации природного ландшафта «под напором посетителей». В связи с этим возникает вопрос о соблюдении строгих требований к сохранению окружающей среды и создании экологических методов использования природных территорий, так как развитие рекреационной деятельности неизбежно ведёт к их изменению. Для решения проблемы преодоления деформации природных территорий авторами сформулированы задачи, которые необходимо выполнить при проектировании ТРК в Арктической зоне.

В статье описаны типы ландшафтов, входящих в АЗРФ, их рекреационные ресурсы и популярные виды туристической деятельности на их территориях. Проанализирована существующая ситуация инфраструктуры на 00ПТ в АЗРФ и описаны необходимые базовые объекты для формирования ТРК. Освещены актуальные проблемы в экологическом праве, препятствующие сохранению 00пТ. Также рассмотрены проблемы соблюдения прав коренных малочисленных народов, проживающих в АЗРФ. В результате анализа отечественных и зарубежных научных материалов сформулированы принципы формирования туристско-рекреационных кластеров на 00ПТ в АЗРФ в целях установление контроля над состоянием экосистем и их сбалансированным использованием.

Ключевые слова: туристско-рекреационный кластер, особо охраняемые природные территории, 00Пт, Арктическая зона, экологическая безопасность, природные ресурсы, туризм в Арктике.
The Formation Principles of the Tourist Recreational Clusters Located at Special Protection Areas of the Arctic Zone

E.Yu.Prokofyeva, MARKHI, Moscow

A.V.Labeznaya, MARKHI, Moscow

The article is devoted to the problem of the formation of tourist and recreational clusters in specially protected natural areas in the Arctic zone of the Russian Federation.

The issues of identifying the peculiarities of interaction between tourism activities in the northern regions in protected areas are not sufficiently developed, which in practice can lead to the loss of valuable natural elements, as well as to the degradation of cities and settlements located directly in the zone of influence of the natural environment. Each new space created in a natural area carries an ecological footprint, and thanks to a constantly evolving society, there is a constant transformation of existing natural structures, which often leads to the degradation of the natural landscape "under the pressure of visitors". This raises the question of ensuring compliance with strict requirements for the preservation of the environment and the creation of ecological methods for the use of natural areas, since the development of recreational activities inevitably leads to their change. To solve the problem of overcoming the deformation of natural areas, the authors formulated tasks that must be performed when designing tourist and recreational clusters in the Arctic zone.

The authors describe the types of landscapes included in the Russian Arctic, their recreational resources and popular types of tourist activities in their territories. The current situation of the infrastructure in protected areas in the Russian Arctic is analyzed and the necessary basic facilities for the formation of tourist and recreational clusters are described. The current problems in environmental law that hinder the conservation of protected areas are highlighted. The problems of observing the rights of indigenous small-numbered peoples living in the Russian Arctic are also considered. As a result of the analysis of domestic and foreign scientific sources, the principles of the formation of tourist and recreational clusters in protected areas in the Russian Arctic are derived, in order to establish control over the state of ecosystems and their balanced use.

Keywords: tourism and recreation cluster, specially protected natural areas, protected areas, Arctic zone, environmental safety, natural resources, tourism in the Arctic. 
Для России последнего десятилетия характерна тенденция масштабного развития экологического туризма в России, примерами которого являются: проведение всероссийского конкурса по созданию туристических рекреационных кластеров ${ }^{1}$, национальный проект «Экология», в рамках которого реализуется Федеральная программа «Сохранение биологического разнообразия и развитие экологического туризма», и принятие стратегии развития Арктической зоны Российской Федерации (АЗРФ), частью которой является положение о развитии арктического туризма. Таким образом, перед Россией стоит перспективная задача создания туристических программ, в которых разнообразные природные ресурсы станут потенциальными зонами «притяжения» для формирования туристско-рекреационных кластеров (ТРК).

Российская Арктика - это экзотическое, малонаселённое и труднодоступное место, которое привлекает к себе внимание путешественников не одно столетие. Наличие суровых климатических условий оказало влияние на сохранение значительных площадей природных территорий в первозданном виде. Естественные леса, степи, луга, тундры, высокогорья, долины рек, висячие и ключевые болота, фьорды и многие другие уникальные природные ландшафты с присущим им диким животным миром в Арктической зоне (АЗ) являются достоянием России. На территории этой зоны проживают коренные малочисленные народы, которые продолжают вести традиционный образ жизни, что является уникальным явлением, поскольку за века они адаптировались к жизни в столь экстремальных климатических условиях. Большой интерес для путешественников представляет уникальный животный мир: лежбища моржей и колонии морских млекопитающих в морях Северного Ледовитого океана, птичьи базары, места нереста лососёвых рыб, стада оленей. В арктических широтах возможно наблюдать полярный день, полярную ночь и северное сияние. Данные рекреационные ресурсы привлекают желающих получить новые эмоции и впечатления, связанные с уникальностью Арктики и экстремальностью её природы.

Туризм в северных регионах - сравнительно новое явление. Первое упоминание о туризме в Российском заполярье относится к концу XIX века, когда впервые вышел в свет путеводитель с подробным описанием путешествия на комфортабельном судне вдоль берегов Кольского полуостров и Южного острова Новой земли [1]. Позже в 1930-х годах сухопутный туризм на Кольском полуострове принял более массовый характер. Впервые в Арктической зоне появляются элементы туристической и рекреационной инфраструктур в виде туристических баз и профилакториев для шахтёров в окрестностях Хибин. С 60-ых по 90-е годы прошлого столетия на Кольском полуострове активно развивались организованный туризм и экскурсионная деятельность, остальная часть Советского

${ }^{1}$ Агентство стратегических инициатив (АСИ) запустило конкурс по созданию туристско-рекреационных кластеров и развитию экотуризма в России (https://asi.ru/news/137329). заполярья оставалась освоенной только самостоятельными туристами. С конца 1990-х годов по настоящее время развивается нормативно-правовая база, в северных городах появляются подразделения региональной власти, которые отвечают за вопросы регулирования и развития туризма.

На сегодняшний день основными активно развивающимися видами туризма в АЗРФ являются: активные комбинированные маршруты на природных территориях, сочетающие виды туристической активности спортивной, приключенческой и научно-познавательной направленности. Посещения носят сезонный характер, и в соответствии с сезоном определяется направление туристических мероприятий. Также несравнимым преимуществом путешествий на Север является возможность знакомства с жизнью и бытом коренного малочисленного населения (КМН), проживающего в основном на территориях традиционного природопользования и 00ПТ и сохранившего традиционный уклад жизни в относительно малоизменённом виде. Популярно среди туристов посещение кочевых стоянок местного населения, участие в обрядах, ежегодных фестивалях и фольклорных праздниках. Среди этнографических программ существует несколько видов туризма: аборигенный экотуризм, этнический, эколого-этнографический, этнологический и этнокультурный. Несмотря на некоторые отличия данных видов туризма, все программы нацелены на знакомство с традициями и культурой разнообразных этносов [1].

Туристическая рекреация в АЗ напрямую связана с использованием туристско-рекреационных ресурсов. Под туристскими ресурсами авторами подразумевается природные, исторические, социально-культурные объекты, которые способны удовлетворять духовные потребности туристов, содействовать восстановлению и развитию физических сил [1]. Одним из главных рекреационных ресурсов АЗ являются арктические природные ландшафты. Они представляют собой совокупность уникальных природных образований и явлений, которые могут быть задействованы в целях туризма.

Обширность АЗРФ предопределяет разнообразие её природных условий и естественных ландшафтов. В административных границах АЗРФ согласно зонально-секторному делению на ландшафтной карте Российской Федерации представлено несколько следующих типов ландшафтов [1; 2].

- Арктические ландшафты распространены на островах Северного Ледовитого океана к северу от $75^{\circ}$ с.ш. В среднем на этих территориях полярная ночь длится 125 суток, и положительная температура воздуха бывает только в июле и августе. Различаются два типа арктических ландшафтов: ледниковые и полярно-пустынные. Ледниковые ландшафты, занимающие большую часть территории архипелага Земли Франца Иосифа, Северной Земли и острова Новой Земли, представляют собой территории, покрытые «ледниковыми куполами» толщиной до 400 м. Из-за преобладания отрицательных температур и экстремальных климатических условий здесь существует только несколько видов снежных растений. 
На ландшафтах полярных пустынь повсеместно распространена вечная мерзлота, средняя температура июля-августа на 1-2 ${ }^{\circ} \mathrm{C}$ выше нуля, арктическая флора небогата, присутствует около 50 видов низкорослых растений. Из млекопитающих наиболее известны северный олень, белый медведь, волк, также на территории распространены птичьи базары [2]. Климат данной территории сильно влияет на условия пребывания туристов на открытом воздухе. В настоящее время посетить высокоширотные районы Российской Арктики можно в рамках морских экспедиционных круизов к Северному полюсу, предусматривающих посещение отдельных территорий архипелагов. Одним из самых популярных мест для посещения является 00ПТ «Национальный парк "Русская Арктика"», расположенный на архипелаге Земля Франца-Иосифа. Режимы посещения данной территории строго регламентированы, отдых здесь носит познавательный характер и заключается в непродолжительных пеших прогулках по проложенным маршрутам малыми группами отдыхающих. Вследствие труднодоступности, короткого сезона для посещения (середина июня - конец августа) и необходимости фрахта ледокола с профессиональной командой данный вид туризма относится к разряду элитарного отдыха [3; 4].

- Субарктические ландшафты, расположенные вдоль побережья Северного Ледовитого океана и по берегам Берингова и 0хотского морей, значительно теплее в летнее время года, и по мере удаления от холодных морей происходит резкая смена нескольких узких подзон - от арктической тундры до лесотундры. На южной границе в июле температура поднимается до $12{ }^{\circ} \mathrm{C}$. Для данных ландшафтов в тёплое время года характерна заболоченность, на них присутствует достаточно богатый растительный покров в виде низкорослых кустарников, ближе к южной границе субарктики появляются деревья (ель, береза, лиственница, тополь). Субарктические ландшафты разделяются на арктотундровые, тундровые и лесотундровые. Первые образуются при переходе от полярных пустынь к типичной тундре, температура самого тёплого время месяца не превышает $6-8^{\circ} \mathrm{C}$, на территории широко распространены «пятнистые тундры» - территории с пятнами голого грунта, лишённые всякой растительности. Тундровые типичные ландшафты отличаются повышенной заболоченностью, средняя температура июля $10{ }^{\circ} \mathrm{C}$, в растительном покрове доминируют кустарники, ближе к югу появляется карликовая берёза. В южных тундровых ландшафтах наблюдается устойчивый период, длительность которого иногда доходит до 60 суток, когда температура держится в районе $+10{ }^{\circ} \mathrm{C}$ и выше. Для этих территорий характерны живописные заросли кедрового стланика. Лесотундровые ландшафты образуют полосу от тундры к тайге, на территории встречается сплошная и островная мерзлота, появляются отдельные деревья, которые к югу переходят в редколесья [2]. Разнообразие природных ландшафтов определяет потенциал для организации разного вида туризма: горная местность - возможность организации активного отдыха в условиях пересечённой мест- ности; наличие судоходных рек - возможность организации отдыха на воде на маломерных судах или организация речных круизов; выход к морскому побережью создаёт возможность привлечения туристов, интересующихся миром дикой природы (киты или птичьи базары) и морскими промыслами коренных народов (охота на морского зверя) [1].

- Бореальные ландшафты распространены преимущественно в северной части умеренного пояса - в континентальном секторе. Местами встречаются участки с многолетней мерзлотой, на территории произрастают еловые, сосновые, пихтовые леса и многое другое. В январе в горных котловинах северо-восточной Сибири температура опускается до $-70{ }^{\circ} \mathrm{C}$ (район Верхоянска и Оймякона). Природные пейзажи очень здесь разнообразны: встречаются криоаридные степи, на территории низкогорья расположены зоны елового и лиственничного редколесья, в высокогорьях много гольцов и каменных россыпей [2]. Наиболее распространёнными видами туризма являются: пешие маршруты, внедорожные туры, водные туры - в летнее время, лыжные походы, снегоходные сафари - в зимний период. Также популяры комбинированные туры, которые включают в себя спортивные мероприятия и ознакомление с природной [1].

В большинстве случаев туристическая деятельность в АЗ неразрывно связана с природой, туристическая активность проявляется в водных походах по рекам и озёрам, лыжных и пеших походах, путешествиях на собачьих или оленьих упряжках и многом другом. Исходя из вышеизложенного можно сказать, что основным видом туризма в АЗ является природо-ориентированный туризм.

На сегодняшний день наиболее развитой инфраструктурой с наибольшим количеством туристических баз, мини-гостинец и организованных частными туроператорами маршрутов на 00Пт отличается Мурманская область. Это связано с её наиболее выгодным экономико-географическим положением и наилучшей транспортной доступностью по сравнению с другими арктическими регионами, а также наличием организованного туризма с конца XIX века. На основе анализа наиболее популярных направлений туризма на Кольском полуострове можно составить типологию видов туристической деятельности [1; 3]. К основным летним туристическим занятиям относятся: езда на велосипедах или внедорожниках в природных парках с выборочным посещением культурно-исторических мест, пешие восхождения, научные-развлекательные экскурсии в ботанический сад «Полярный», где посетители могут познакомится с местной фауной, посещение археологических достопримечательностей в горных массивах Хибины и Ловозеро, знакомство с культурно-историческим наследием терских поморов на 00Пт «Терский берег» (музеи, национальные праздники, общение с местным населением), длительные велопоходы и проживание в кемпингах, осмотр памятников военной истории на полуостровах Средний и Рыбачий (северо-западная часть Кольского полуострова). В зимнее время популярны 
снегоходные сафари по природным территориям Кольского полуострова и длительные лыжные походы в Хибинских и Ловозерских горных массивах продолжительностью от нескольких часов до нескольких дней. Несмотря на большое количество частных агентств, занимающихся организацией туров в АЗ в Мурманской области, туристическая инфраструктура на 00ПТ развита очень слабо. На Кольском полуострове в основном для проживания туристов используются каркасные палатки и автономные электрогенераторы, автономное санитарное оборудование, иногда туристы проживают в частном секторе или в балка́х

Увеличение количества 00ПТ и национальных парков в АЗРФ существенно активизировало туризм. Однако, по сравнению с зарубежными арктическими странами, в России рекреационные ресурсы в полярных регионах используются не в полной мере. Дальнейшее развитие и функционирование туристического сектора во многом зависит от организации ТРК.

ТРК формируются на 00ПТ с целью организации новых и упорядочивания сложившихся туристических потоков между территориально сближенными культурно-историческими или природными объектами и создания поддерживающей инфраструктуры с участием государственного финансирования (дороги, водопроводные и канализационные сети, электросети, коммуникации, трубопроводы и т.д.) и для формирования туристической инфраструктуры (проживание, питание, базы отдыха, экскурсии и т. д.) с привлечением частных инвестиций. Таким образом, при формировании ТРК создаются дополнительные рабочие места, увеличиваются налоговые

${ }^{2}$ Бало́к - практически любая временная некапитальная постройка небольшого размера, часто из подручных материалов, используемая как гараж, строительная бытовка или домик отдыха и которую можно целиком переместить с места на место (https://zen.yandex.ru/media/id/5a90258f77d0e61cefdb6655/ chto-takoe-nastoiascii-balok-5d6e7b3235ca3100ad89d779).

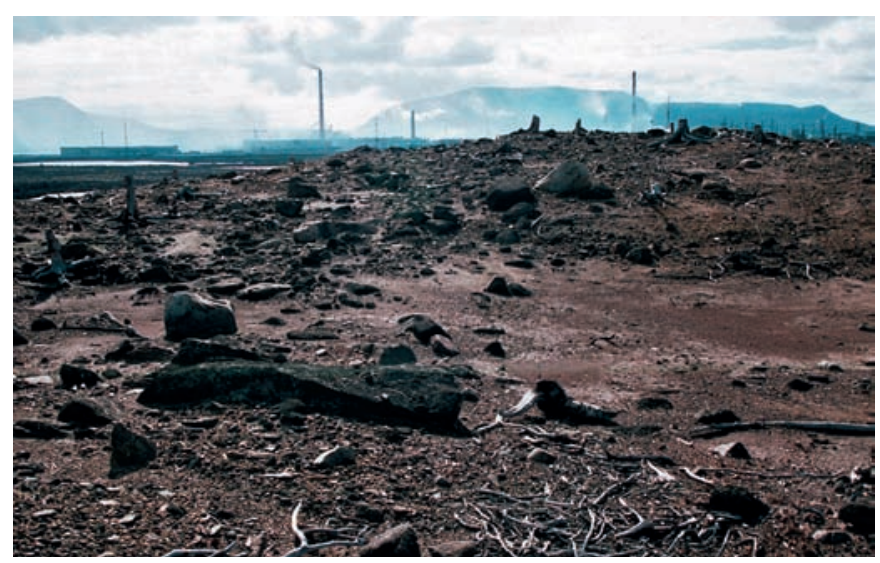

Рис. 1. Последствия антропогенного воздействия на территории АЗРФ. Выбросы сернистых газов от медно-никелевых комбинатов в городах Мончегорске и Никеле в Мурманской области сформировали вокруг них антропогенные пустоши (источник: https://www.hcvf.ru/ru/publications/ sohranenie-tsennih-prirodnih-territoriy-severo-zapada-rossiianaliz-reprezentativnosti) поступления в федеральный и муниципальный бюджеты, что, в свою очередь, позволяет направить полученные доходы на защиту окружающей среды и сохранение уникальных ландшафтов. Также размещение объектов туристской и обеспечивающей инфраструктур способствует популяризации туризма в А3. К базовым элементам инфраструктуры ТРК относятся: визит-центры, входные группы, автомобильные стоянки, административно-хозяйственные блоки, санитарно-бытовые сооружения, экологические тропы (экстремальные, походные, прогулочные, экскурсионные, общего доступа), смотровые площадки (естественного происхождения, искусственные), средства навигации, информирования и регламентирования, элементы благоустройства территории для разновозрастных групп, людей с ограниченными возможностями и других маломобильных групп, объекты инженерной инфраструктуры для обеспечения безопасности на маршрутах, размещения системы освещения в местах привалов на дальних маршрутах), площадки для кемпинга, малые архитектурные формы для отдыха на территории 00ПТ, объекты для размещения гостей на близлежащих территориях вне границ 00ПТ (гостевые дома, группы объектов сферы обслуживания) [4; 5].

Формирование ТРК на О0ПТ является диверсификацией природопользования. Это путь, по которому пошли многие приарктические государства. Рекреационное, природоохранное и традиционное природопользование в зарубежных приарктических государствах стало альтернативой промышленному пути развития [6]. Рекреация в АЗ является важным элементом структуры рационального природопользования в арктических зонах в Дании, Канаде, США, Исландии, Норвегии, Финляндии и Швеции, она обеспечивает сбалансированное использование территорий, стимулирует природоохранную деятельность, создаёт новые рабочие места, возможности сохранения экологической обстановки в А3, значительные территории которой являются важнейшими звеньями биосферного экологического каркаса.

Несмотря на то, что российское законодательство направлено на формирование устойчивого развития урбанизированных и природных территорий в целях обеспечения благоприятных условий и безопасности жизнедеятельности ${ }^{3}$, а также контроль за негативными воздействиями на окружающую среду и рациональным использованием природных ресурсов, ряд территорий в АЗ не демонстрирует эффект декаплинга ${ }^{4}$ (рис. 1). В целом, существенного продвижения

3 Федеральный закон от 23.11.2009 N 261-Ф3 (ред. от 26.07.2019) «0б энергосбережении и о повышении энергетической эффективности и о внесении изменений в отдельные законодательные акты Российской Федерации».

${ }^{4}$ Декаплинг (от англ. decoupling) - представляет собой «стратегическую основу движения к экологически устойчивой экономике, позволяющей согласовывать темпы роста благосостояния людей, с одной стороны, и потребления ресурсов и экологического воздействия, с другой». Эффект декамплинга можно интерпретировать в показателях природёмкости, отражающих объемы затрат природных ресурсов и загрязнений на единицу конечного результата, - ВВП (https://sciarticle.ru/stat.phpi=dekapling_kak_faktor_razresheniya_protivorechiya_mezhdu_ uvelicheniem_narodonaseleniya_i_realizaciey_koncepcii_zelenoy_ekonomiki). 
в улучшении экологической ситуации в АЗРФ не наблюдается. Доказательством этого может послужить состояние водных ресурсов в Мурманской области [7]. А отсутствие организованных туристско-рекреационных кластеров может привести к стихийной эксплуатации рекреационных ресурсов.

К региональным особенностям охраны природы в АЗ относится слабая способность к восстановлению природных комплексов по отношению к антропогенным воздействиям. Все природные процессы проходят замедленно, в случае нанесения ущерба разрушение сложившихся экосистем происходит очень быстро, и особенно уязвимы комплексы в районах Крайнего Севера. Сохранение природных территорий становится одной из приоритетных задач для государства. Немногие масштабные территории природных ландшафтов A3, могут играть не только роль экологического компенсатора мирового значения, но и способны к реализации на них программ экономического развития на основе сохранения и предоставления в использование фрагментов естественной биосферы [8]. Одним из таких направлений может стать экологический туризм в АЗРФ.

На сегодняшний день доля экологического туризма в России составляет около 1\% в общей структуре отечественного туристического рынка. Главными препятствиями развития данной отрасли являются: высокая чувствительность множества экосистем к антропогенным воздействиям, отсутствие комплексного прогнозирования, долгосрочного планирования и территориальной организации туризма на государственном уровне [9].

В России термин «экологический туризм» используется с середины 1980-х годов, при этом окончательной классификации видов туризма в Российском законодательстве в настоящий момент не существует [9]. В Федеральной целевой программе «Развитие внутреннего и въездного туризма в Российской Федерации (2011-2018 годы)» ${ }^{5}$ упоминается экологический туризм без указания видов туристической деятельности с их отличительными особенностями, в Концепции развития системы особо охраняемых природных территорий федерального значения на период до 2020 года 6 отмечено, что «познавательный туризм является одним из специализированных видов экологического туризма, основной целью которого является ознакомление с природными и культурными достопримечательностями», при этом отличия одного вида туризма от другого (например, обозначения различий между экологическим и сельским туризмом) в данном документе не представлены, также как и правовые последствия таких отличий [9]. Согласно определению, предложенному Международным союзом охраны природы и природных ресурсов, главные цели экологического туризма - это изучение природных и культурно-этнографических ландшафтов, которое содействует охране природы и создаёт экономические условия, выгодные для местного населения [10]. Для градостроительного планирования и развития 00ПТ в целях формирования ТРК необходимы конкретные определения видов туризма, которые могут быть приняты за основу. Это будет способствовать популяризации экологического туризма и более ясному социальному и экономическому планированию 00ПТ и близлежащих территорий в регионах А3.

Актуальными проблемами в экологическом праве также являются неточности в формулировках категорий 00ПТ, что ставит вопрос о границах формируемых ТРК и связанных с этим ограничениях рекреационной деятельности. Экологический туризм может осуществляться на 00ПТ всех категориях, кроме заповедников. Согласно классической концепции заповедования ${ }^{7}$ в целях сохранения природных комплексов в естественном виде на данных территориях запрещена любая хозяйственная деятельность, исключением является проведение научных исследований. Несколько лет назад в законодательную формулировку о задачах заповедника были внесены изменения: вместо задачи «экологическое просвещение» была внесена новая задача «экологическое просвещение и развитие познавательного туризма» [9], что несомненно ставит под угрозу местные экосистемы заповедников.

В правовой охране земель актуальными видятся проблемы обеспечения безопасной рекреационной деятельности на 00ПТ. Негативные последствия массового посещения туристами заповедных зон уже демонстрируют ряд территорий в А3. К примеру, в Пинежских пещерах в Архангельской области нарушение теплового баланса вследствие массового посещения пещер привело к гибели значительного количества летучих мышей [11]. Выходом из сложившийся ситуации являются развитие экологического контроля и мониторинга территорий, проведение экологического аудита, а также соблюдение нормативов предельных рекреационных нагрузок. В Федеральном законе «0б охране окружающей среды» (от 10.01.2002 № 7-Ф3) предусмотрены нормативы предельно допустимой антропогенной нагрузки (ст. 27. Нормативы до-

\footnotetext{
${ }^{5}$ Федеральная целевая программа «Развитие внутреннего и въездного туризма в Российской Федерации (2011-2018 годы)» утверждена Постановлением Правительства РФ от 2 августа 2011 г. № 644 «0 Федеральной целевой программе "Развитие внутреннего и въездного туризма в Российской Федерации (2011-2018 годы)"» (https://base.garant.ru/55171986/).

${ }^{6}$ Концепция развития системы особо охраняемых природных территорий федерального значения на период до 2020 года» (вместе с «Планом мероприятий по реализации Концепции развития системы особо охраняемых природных территорий федерального значения на период до 2020 года») утверждена Распоряжением Правительства РФ от 22.12.2011 № 2322-р «0б утверждении Концепции развития системы особо охраняемых природных территорий федерального значения на период до 2020 года» (http://www.consultant.ru/document/cons_doc_LAW_124870/).

7 Заповедование - один из способов охраны природных культурно-исторических ценностей, выражающийся в полном либо частичном (без ущерба для окружающей природной среды) запрещении их использования в целях сбережения этих ценностей для науки и культуры как национального достояния настоящих и будущих поколений. «Заповедный» означает неприкосновенный, запретный (https://studopedia.ru/5_82142_nyaemih-prirodnih-territoriy.html).

${ }^{8}$ https://base.garant.ru/12125350/3e01a7fa47957b2f627d012fe630f5c6/.
} 
пустимой антропогенной нагрузки на окружающую среду $)^{8}$, которые должны определять степень антропогенного воздействия, при превышении которого происходит разрушение экосистем. В тоже время нормативного акта с методикой расчёта антропогенной нагрузки на уникальные природные комплексы не существует. На сегодняшний день на практике нормативы допустимой антропогенной нагрузки установлены только на уникальные территории экологической системы Байкал ${ }^{9}$ [9]. Поэтому в условиях экспансии рекреационной деятельности на 00ПТ необходимость закрепления в системе законодательства нормативных актов с расчётами пропускной способности для каждой конкретной 00ПТ в целях сохранения природных комплексов АЗ и развития экологического туризма приобретает особое значение. Решение вышеперечисленных и других препятствующих развитию рекреационной деятельности проблем позволят стимулировать экологический туризм, снизив существенные риски развития данной отрасли.

Немаловажной проблемой является соблюдение прав коренных малочисленных народов (КМН), проживающих в АЗРФ. Экологический туризм выполняет ряд социальных функций, связанных с поддержкой разных местных общин. Социальная функция экологического туризма - это создание новых рабочих мест, развитие традиционных форм природопользования, стимулирование производства экологических продуктов, инвестиции в охрану природы, а также возможность роста благосостояния КМН РФ. Для реализации вышеперечисленных социальных функций экологический туризм необходимо развивать не только на территориях 00ПТ, но и на территориях традиционного природопользования (ТТП). Главными целями ТТП являются сохранение и развитие традиционного образа жизни КМН. Важно отметить, что в 2013 году ТТП были исключены из перечня 00ПТ [9], что повлекло за собой ухудшение условий жизни данных народов вследствие строительства промышленных предприятий и разработки недр без проведения экологических экспертиз и без общественного обсуждения. Решением данной проблемы могло бы стать придание землям ТТП статуса 00Пт, а развитие экологического туризма может способствовать росту благосостояния местных общин, многие из которых к тому же проживают на депрессивных территориях.

Установление контроля над состоянием экосистем, развитием и ростом урбанизированных территорий, а также над сбалансированным использованием природной среды - это приоритетные для современного общества задачи. Необходимы программы по выстраиванию связей между потребностями общества и возможностями природной среды и создание новых подходов, с помощью которых человек использует природное окружение в рекреационных целях, не разрушая

${ }^{9}$ Приказ Минприроды России от 5 марта 2010 г. № 63 «0б утверждении нормативов предельно допустимых воздействий на уникальную экологическую систему озера Байкал и перечня вредных веществ, в том числе веществ, относящихся к категориям особо опасных, высокоопасных, опасных и умеренно опасных для уникальной экологической системы озера Байкал». при этом сложившиеся экосистемы [12]. Отсюда возникает необходимость удовлетворения потребностей населения без нанесения непоправимого ущерба окружающей среде?

На сегодняшний день главным для решения этого вопроса должна стать разработка новых градостроительных и архитектурно-ландшафтных проектов, которые не только будут способствовать сохранению 00ПТ, но и стимулировать деградирующие природные территории к восстановлению. Достижение некоего «экологического равновесия» необходимо для создания условий, при которых природная среда будет способна к самоподдержанию в условиях рекреационной нагрузки. В связи с этим перед архитекторами и градостроителями встают актуальные вопросы, связанные с предметом проектирования и строительства на особо охраняемых природных территориях:

- как инфраструктура ТРК должна взаимодействовать с природным окружением?

- как повлияет использование природных территорий в рекреационных целях на местные экосистемы?

- станет ли преобладающая территория дикой природы сплошным рекреационным образованием?

Данные рассуждения направлены на необходимость соблюдения строгих требований к сохранению окружающей среды, создания экологических методов использования природных территорий, так как развитие рекреационной деятельности неизбежно ведёт к изменению природной среды, и все техногенные воздействия должны быть к ней адаптированы. Решением для данной ситуации должны стать «... формы симбиотического существования, коэволюции искусственной и природной среды» [12]. Необходимо определить новые подходы к формированию пространства, которые раскроют рекреационный потенциал природных территорий и обеспечат сохранение природной среды, и предложить архитектурные и ландшафтные решения, которые будут способствовать восстановлению природной среды.

Проблема преодоления деформации природных территорий, входящих в ТРК, а также природных территорий, расположенных непосредственно в зоне их влияния, связана как с определением научно обоснованных методов проектирования, так и с возможностью конкретной территории выдерживать определённый уровень антропогенной нагрузки [13]. Вопросы выявления специфики туристической деятельности в северных регионах на 00ПТ не достаточно разработаны, что на практике может привести к утрате ценных природных элементов, а также к деградации городов и поселений, находящихся непосредственно в зоне влияния природного окружения. Таким образом, возникает объективная необходимость исследования архитектурно-ландшафтных принципов формирования ТРК, обеспечивающих сохранение природной среды на 00ПТ в условия АЗ.

В результате анализа зарубежного и отечественного опыта проектирования ТРК на 00ПТ [4; 5; 14] сформулированы задачи, решение которых является обязательным для сохранения 
природных территорий. При проектировании архитектурноландшафтных комплексов на 00ПТ необходимо:

- использование возобновляемых источником энергии;

- использование экологического транспорта на 00Пт;

- максимальное сохранение существующих природных и озеленённых территорий;

- переработка отходов;

- определение границ территорий открытых для посещения, учёт пропускной способности каждой отельной территории;

- очищение воды, воздуха, почвы, восстановление их природных свойств;

- экологичные объёмно-планировочные, конструктивные и архитектурные решения инфраструктуры ТРК;

- просветительская и научно-образовательная направленность проектов ТРК.

В результате анализа отечественных и зарубежных материалов и экологических и природоориентированных подходов в проектировании, разработанных В.А. Ильичевым, М.В. Шубенковым, Г.А. Птичниковой, Н.А. Ястребовой, Г.В. Есауловым, В.Н. Логвиновым и многими другими, зарубежного [14] и отечественного [4; 5] опыта проектирования ТРК на ООПТ и принципов проектирования архитектурно-градостроительных структур на основе биосферной совместимости с природными комплексами [13] выведены архитектурно-ландшафтные принципы формирования туристско-рекреационных кластеров на особо охраняемых природных территориях в Арктической зоне.

1. Принцип биоцентризма предполагает нестандартизированное нормирование допустимых антропогенных нагрузок на ценные природные территории, выраженное в количестве посещений на выделенных участках территории в определённый отрезок времени. Под ценными природными территориями (ЦПТ) подразумеваются «природные комплексы разных уровней сложности - биотопы и их компоненты, а также другие структурные единицы организации сообществ и экосистем, которые обладают одним или несколькими признаками природоохранной ценности» [15]. Соответственно выделяя ЦПт по критериям природоохранной ценности, каждому участку отводится определённый уровень концентрации туристических потоков. С точки зрения архитектуры, данный принцип влияет на структуру ТРК и формирование туристических маршрутов, а также на пространственное развитие инфраструктуры кластера. Каждая 00пт должна проходить экологический аудит на предмет границ и состояния ЦПТ, и при первых признаках нарушения местных комплексов биотипов необходимо ограждать данные территории от массового посещения для возможности восстановления ценных биотипов. Из вышеизложенного следует, что сети туристических маршрутов в АЗ должны быть нестационарного характера и при необходимости изменяться в соответствии с состоянием местных природных сообществ. Данный принцип способствует сохранению уязвимых природных комплексов А3, а также экологическому просвещению посетителей (рис. 2).
2. Принцип биоморфизма (или бионики) реализуется при создании архитектурно-ландшафтных комплексов за счёт повторения форм, линий и цветов живой природы, в которых прообраз природных объектов определяет архитектурнохудожественный образ. «Пространственные формы, морфологически сходные с природными, могут отталкиваться от зооморфных, фитоморфных, а также пластичных геоморфных форм, как бы вырастающих естественным образом из земли, с ограниченной интеграцией архитектуры и природного ландшафта». Данный принцип обеспечивает возможность формирования гармоничной и «невидимой» инфраструктуры на 00ПТ с целью максимального сохранения естественных природных ландшафтов в первозданном виде [16-18]. Все элементы интегрируемой архитектурой в природное окружение, а именно: форма, декор, используемые строительные материалы, конструкция, - должны быть подчинены природному окружению.

Музей «Кит» («The Whale»), спроектированный датской архитектурной фирмой «Дарт Мэндрап» («Dorte Mandrup»), наглядно иллюстрирует принципы биоморфизма в архитектуре в условиях АЗ. Проектом предлагается разместить здание музея на острове Андёя (Andøya), расположенном в трёхстах

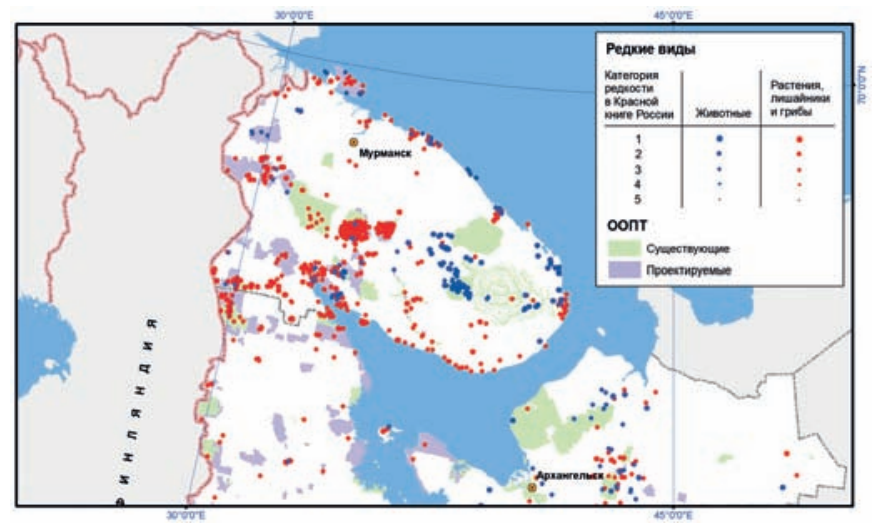

Рис. 2. Пример выявления ЦПт: мест обитания редких видов, занесённых в Красную книгу России (изображение из открытых источников сети Интернет)

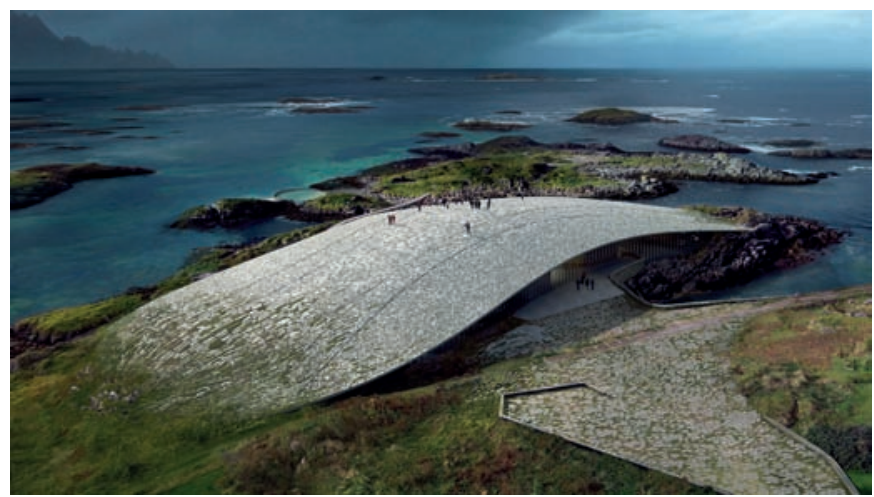

Рис. 3. Музей, посвящённый сохранению и истории китов на севере Норвегии. Визуалиация. Проект датской архитектурной фирмы «Дарт Мэндрап» («Dorte Mandruр») (изображение из открытых источников сети Интернет) 
километрах от полярного круга на уникальной природной территории, являющейся одним из лучших мест для наблюдения за китами. Здание является продолжением природного ландшафта - изогнутая крыша, покрытая местным натуральным камнем, который в дальнейшем по задумке авторов должен зарасти мхом, имитирует естественный земляной покров. Сливаясь с местностью, музей возвышается на над берегом как холм естественного происхождения, тем самым сохраняя первозданный природный пейзаж (рис. 3).

Другой пример биоморфизма в архитектуре демонстрирует центр в арктическом национальном парке «АРК» («The Arc») на острове Шпицберген, расположенном на $78^{\circ}$ к северу от экватора у побережья Норвегии. Спроектированный архитектурным бюро «Снохетта» («Snøhetta»), парк является уникальным примером интеграции крупномасштабной не нарушающей окружающий ландшафт архитектуры в природную среду. Каркас из поперечно-клеёной древесины в сочетании с дисками из массива дерева образует форму высокой монолитной башни, фасады которой отражают свет сливаясь с вечно белоснежной пустыней острова (рис. 4).

3. Биомиметические принципы (БМ) в отличие от принципов биоморфизма основаны на изучении природных процессов. В основе принципа лежит междисциплинарный подход в проектировании, который включает в себя изучение природных типологий и процессов, протекающих в природе. БМ-принципы основаны на природныхпроцессах, таких как метаболизм, обмен энергией, веществами и информацией, гомеостаз, стремление к поддержанию устойчивого состояния, целенаправленная совокупность взаимосвязанных действий которых впоследствии заимствуется в проектировании с целью создания организованной системы, подчинённой единым законам природы. На сегодняшний день это направление приобретает всё большую популярность в мире, однако реализованного «архитектурного»

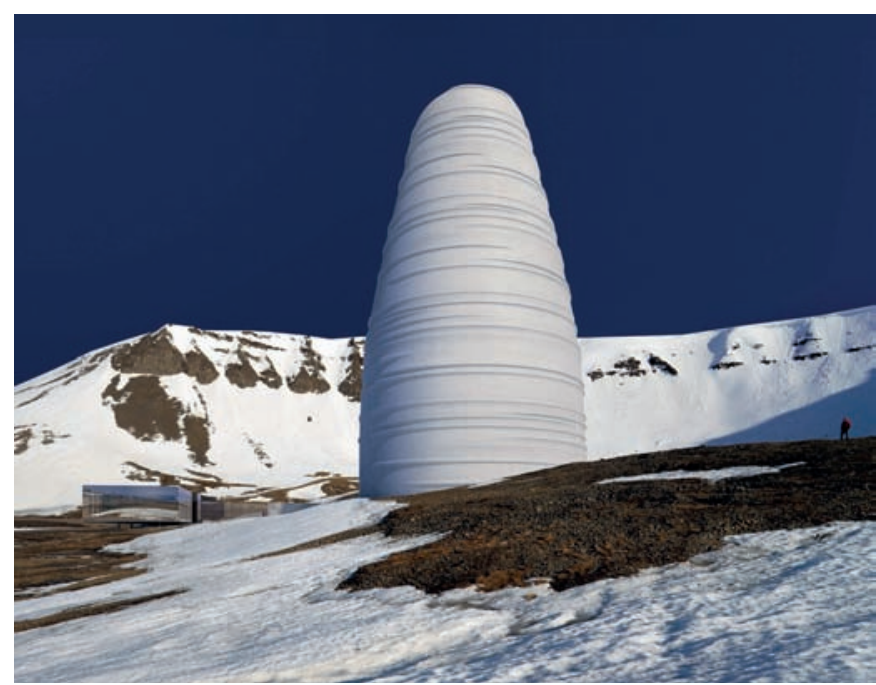

Pис. 4. Проект выставочного центра на острове Шпицберген. Архитектурное бюро «Снохетта» («Snøhetta»). Фото из открытых источников сети Интернет аналога природной экосистемы пока ещё не существует. Во множестве концептуальных архитектурных проектах можно увидеть попытки использования характеристик экосистемы. Данный принцип направлен на выстраивание баланса и воссоздание взаимосвязей естественной и искусственной сред, повышение адаптационных характеристик архитектурных объектов и градостроительных систем [17; 19].

Биомиметика с каждым годом набирает популярность среди архитекторов и градостроителей в зарубежных странах. Все большее количество архитектурных бюро в мире работают с биологическими технологиям, которые открывают новые возможности в проектировании. Одной из первых лабораторий генетической архитектуры является лаборатория «Биоцифровая архитектура и генетика», возглавляемая испанским исследователем Альберто Эстевецем. Область интересов исследователей данной лаборатории - «биоцифровая архитектура», которая является слиянием архитектуры, генетики, кибернетики. Генетические исследования проводятся учёными в тандеме: генетики, биологи и архитекторы работают над проектами по разработке новых строительных материалов с целью создания архитектуры, пригодной для вторичной переработки, экологически чистой, способной к самостоятельному естественному росту [20].

Данные технологии обладают огромным потенциалом и бросают вызов учёным и архитекторам. Исследование БМпринципов - это возможность формирования архитектурноландшафтных комплексов на 00ПТ, которые бы охватывали природные территории как новая «архитектурная растительность».

\section{Лuтература}

1. Цекина, М.В. Оценка туристско-рекреационного потенциала Российского Заполярья: дис. на соиск. учен. степ. канд. географических наук (25.00.24) / Цекина Мария Викторовна; Москва. Моск. гос. ун-т им. М.В. Ломоносова. - М., 2014-167 с.

2. Голубчиков, С.Н. Введение в Российское североведение : Учеб. пособие для студентов вузов по геогр. спец. / С.Н. Голубчиков, П.Х. Зайдфудим. - М. : Изд-во Арт-Пейпер-принт, 2003. - 283 c.

3. Грушенко, Э.Б. Экологический туризм как фактор устойчивого развития Западной Арктики / Э.Б. Грушенко // Арктика и Север. - 2018. - № 32. - С. 18-29.

4. Максанова, Л.Б. Лучшие практики экологического туризма в Российской Федерации / Л.Б. Максанова. - М. : Изд-во Российского экономического университета им. Г.В. Плеханова, 2018. - 168 с.

5. Руководство по проектированию объектов инфраструктуры на 00Пт [Электронный ресурс] // Агентство стратегических инициатив. Официальный сайт. - Режим доступа: https://old. asi.ru/library/ecotourism/120678 (дата обращения: 18.01.2021).

6. Красовская, Т.М. Природопользование Севера России / Т.М. Красовская. - М. : Изд-во ЛКИ, 2008. - 288 с.

7. Скуфьина, Т.П. Вопросы развития российской Арктики в контексте экологических проблем / Т.П. Скуфьина, Е.А. 
Бажутова // Арктика: инновационные технологии, кадры, туризм : материалы международной науч. практ. конф. Воронеж, 19-21 ноября 2018 г. - Воронеж, 2018. - С. 443-446.

8. Родоман, Б.Б. Экологическая специализация - желательное будущее для большей части России / Б.Б. Родоман // Известия Российской академии наук. Серия географическая. - 2016. - № 4. - С. 140-147.

9. Алексеева, А.П. Современные проблемы теории экологического права : монография / А.П. Алексеева, А.П. Анисимов, В.А. Волколупова. - М. : Изд-во Юрлитинформ, 2019. - 511 с.

10. Международный союз охраны природы и природных ресурсов. Официальный сайт. - Режим доступа: https://www. iucn.org/ru (дата обращения: 25.10.2020).

11. Шаврина, E.В. Экология пещер европейского севера России: проблемы использования и пути сохранения [Электронный ресурс] // Минералогия техногенеза : материалы международной науч. практ. конф. - Миасс-Кунгур, 2006. - Режим доступа: http://www.nordspeleo.ru/karst/st_karst/ ecopecher.htm (дата обращения 07.10.2020).

12. Шубенков, М.В. Симбиотическое развитие урбанизированных и природных территорий / М.В. Шубенков, М.Ю. Шубенкова, К.К. Карташова // Международный электронный научно-образовательный журнал «АМІТ» [Электронный ресурс]. - Режим доступа: https://marhi.ru/АМIT/2019/4kvart19/ PDF/14_shubenkov.pdf (дата обращения 19.09.2020).

13. Птичникова, Г.А. Ландшафтно-градостроительные предложения по формированию поселений на принципах биосферной совместимости с особо охраняемым природным комплексом (на примере территорий Волго-Ахтубинской поймы) / Г.А. Птичникова // Изучение, сохранение и восстановление естественных ландшафтов : материалы науч. практ. конф. Волгоград, 12-16 октября 2015 г. - М. : Планета, 2015. - С. 24-29.

14. Международный опыт развития экологического туризма на особо охраняемых природных территориях [Электронный ресурс]. // Агентство стратегических инициатив. Официальный сайт- Режим доступа: https://old.asi. ru/library/ecotourism/116263 (дата обращения: 18.01.2021).

15. Сохранение ценных природных территорий Северо-Запада России. Анализ репрезентативности сети 00пт Архангельской, Вологодской, Ленинградской и Мурманской областей, Республики Карелии, Санкт-Петербурга [Электронный ресурс] / Коллектив авторов. Под ред. Кобякова К.Н. - СПб, 2011. - Режим доступа: https://www.hcvf.ru/pub_doc/ GAP.pdf (дата обращения 14.09.2020). Русс. Англ. аннот

16. Лебедев, Ю.С. Архитектурная бионика / Ю.С. Лебедев. - М. : Стройиздат, 1990. - 269 с.

17. Есаулов, Г.В. Архитектура в природе, природа в архитектуре: парадигмы развития / Г.В. Есаулов // Материалы академических чтений «Архитектура в природе, природа в архитектуре». Кисловодск, 2009. - Москва-Кисловодск, 2009. - С. 30-58.

18. Есаулов, Г.В. Устойчивая архитектура - от принципов к стратегии развития / Г.В. Есаулов // Вестник Томского го- сударственного архитектурно-строительного университета - 2014. - № 6 (47). - С. 9-24.

19. Гридюшко, А.Д. Биомиметические принципы в архитектурном проектировании: автореф. дис. на соиск. учен. степ. канд. арх. наук (05.23.21) / Гридюшко Анна Дмитриевна; Москва. гос. Моск. архитектур. ин-т. - М., 2013 - 34 с.

20. Estévez, Alberto T. Biodigital Architecture //Computation: The new realm of architectural design / Ed. ECAADe. - Istanbul, 2009. - Р. 681-686.

21. Логвинов, В.Н. Природа и архитектура. Путь интеграции / В.Н. Логвинов. - М., 2019. - 218 с.

\section{References}

1. Tsekina M.V. Otsenka turistsko-rekreatsionnogo potentsiala Rossiiskogo Zapolyar'ya [Assessment of the tourist and recreational potential of the Russian Arctic]. Candidate's thesis. Moscow, 2014, 167 p. (In Russ.)

2. Golubchikov S.N., Zaidfudim, P.Kh. Vvedenie v Rossiiskoe severovedenie [Introduction to Russian Northern Studies]. Moscow, Art-Pejper-print Publ., 2003, 283 p. (In Russ.)

3. Grushenko E.B. Ekologicheskii turizm kak faktor ustoichivogo razvitiya Zapadnoi Arktiki [Ecological tourism as a factor of sustainable development of the Western Arctic]. In: Arktika i Sever [Arctic and North], 2018, no. 32, pp. 18-29. (In Russ.)

4. Maksanova L.B. Luchshie praktiki ekologicheskogo turizma $\checkmark$ Rossiiskoi Federatsii [Best practices of ecological tourism in the Russian Federation]. Moscow, Publishing house of the Russian University of Economics. G.V. Plekhanov, 2018, 168 p. (In Russ.)

5. Rukovodstvo po proektirovaniyu ob"ektov infrastruktury na 00PT [Guidelines for the design of infrastructure facilities in protected areas]. Agentstvo strategicheskikh initsiativ. Ofitsial'nyi sait [Agency for Strategic Initiatives. Official site]. - Access mode: https://old.asi.ru/library/ecotourism/120678 (accessed 18.01.2021) (In Russ.)

6. Krasovskaya T.M. Prirodopol'zovanie Severa Rossii [Nature management of the North of Russia]. Moscow, LKI Publ., 2008, 288 p. (In Russ.)

7. Skuf'ina T.P., Bazhutova E.A. Voprosy razvitiya rossiiskoi Arktiki v kontekste ekologicheskikh problem [Development of the Russian Arctic and environmental problems economic development]. In: Arktika: innovatsionnye tekhnologii, kadry, turizm. Materialy mezhdunarodnoi nauch. prakt. konf. [Arctic: innovative technologies, personnel, tourism. Materials of international scientific. practical conf.] Voronezh, November 19-21, 2018. Voronezh, 2018, pp. 443-446. (In Russ.)

8. Rodoman B.B. Ekologicheskaya spetsializatsiya zhelatel'noe budushchee dlya bol'shei chasti Rossii [Ecological Specialization as the Desirable Future for the Most Part of Russia]. In: Izvestiya Rossijskoj akademii nauk. Seriya geograficheskaya [Bulletin of the Russian Academy of Sciences. Geographic series] 2016, no. 4, pp. 140-147. (In Russ., abstr. in Engl.)

9. Alekseeva A.P. Sovremennye problemy teorii ekologicheskogo prava: monografiya [Modern problems of the 
theory of environmentallaw]. Moscow, YUrlitinform Publ., 2019, 511 p. (In Russ.)

10. Mezhdunarodnyi soyuz okhrany prirody i prirodnykh resursov: ofitsial'nyi sait [International Union for Conservation of Nature and Natural Resources]. Access mode: https://www. iucn.org/ru (accessed 10/25/2020).

11. Shavrina, E.V. Ekologiya peshcher evropeiskogo severa Rossii: problemy ispol'zovaniya i puti sokhraneniya [Ecology of caves in the European north of Russia: problems of use and ways of conservation]. In: Mineralogiya tekhnogeneza. Materialy mezhdunarodnoi nauch. prakt. konf. [Mineralogy of technogenesis. Materials of international scientific. practical con]. Miass-Kungur, 2006. Access mode: http://www.nordspeleo.ru/ karst/st_karst/ecopecher.htm (accessed 10/07/2020).

12. Shubenkov M.V., Shubenkova M.YU., Kartashova K.K. Simbioticheskoe razvitie urbanizirovannyh i prirodnyh territoriy [Symbiotic development of urbanized and natural areas] In: AMIT. Access mode: https://marhi.ru/AMIT/2019/4kvart19/PDF/14_ shubenkov.pdf (accessed 09/19/2020). (In Russ., abstr. in Engl.)

13. Ptichnikova G.A. Landshaftno-gradostroitel'nye predlozheniya po formirovaniyu poselenii na printsipakh biosfernoi sovmestimosti s osobo okhranyaemym prirodnym kompleksom (na primere territorii Volgo-Akhtubinskoi poimy) [Landscape and urban planning proposals for the formation of settlements based on the principles of biosphere compatibility with a specially protected natural complex (on the example of the territories of the Volga-Akhtubinskaya floodplain)]. In: Izuchenie, sokhranenie $i$ vosstanovlenie estestvennykh landshaftov. Materialy nauch. prakt. konf. [Study, conservation and restoration of natural landscapes. Scientific materials. practical conf.]. Volgograd, October 12-16, 2015. Moscow, Planeta Publ., 2015, pp. 24-29. (In Russ.)

14. Mezhdunarodnyi opyt razvitiya ekologicheskogo turizma na osobo okhranyaemykh prirodnykh territoriyakh: sait Agentstvo strategichesikkh initsiativ. [International experience in the development of ecological tourism in specially protected natural areas]. Assecc mode: https://old.asi.ru/ library/ecotourism/116263 (accessed 01/18/2021). (In Russ.)

15. Kobyakov K.N. (ed.). Sokhranenie tsennykh prirodnykh territorii Severo-Zapada Rossii. Analiz reprezentativnosti seti 00PT Arkhangel'skoi, Vologodskoi, Leningradskoi i Murmanskoi oblastei, Respubliki Karelii, Sankt-Peterburga [Conservation of valuable natural areas of the North-West of Russia. Analysis of the representativeness of the network of specially protected natural areas of the Arkhangelsk, Vologda, Leningrad and Murmansk regions, the Republic of Karelia, Saint Petersburg]. St. Petersburg, 2011. Access mode: https://www.hcvf.ru/pub_doc/ GAP.pdf (accessed 09/14/2020). (In Russ., abstr. in Engl.)

16. Lebedev Yu.S. Arkhitekturnaya bionika [Architectural bionics]. Moscow, Stroiizdat Publ., 1990, 269 p. (In Russ.)

17. Esaulov G.V. Arkhitektura $\vee$ prirode, priroda $v$ arkhitekture: paradigmy razvitiya [Architecture in nature, nature in architecture: development paradigms]. In: Materialy akademicheskih chtenij "Arhitektura $v$ prirode, priroda $v$ arhitekture» [Materials of academic readings "Architecture in nature, nature in architecture"], Kislovodsk, 2009. MoscowKislovodsk, 2009, pp. 30-58. (In Russ.)

18. Esaulov G.V. Ustoichivaya arkhitektura - ot printsipov k strategii razvitiya [Sustainable architecture - from principles to development strategy]. In: Vestnik Tomskogo gosudarstvennogo arkhitekturno-stroitel'nogo universiteta [Bulletin of the Tomsk State University of Architecture and Civil Engineering], 2014, no. 6 (47), pp. 9-24. (In Russ.).

19. Gridyushko A.D. Biomimeticheskie printsipy v arkhitekturnom proektirovanii [Biomimetic principles in architectural design]. Extended abstract of candidate's thesis. Moscow, 2013, 34 p. (In Russ.).

20. Estévez Alberto T. Biodigital Architecture [Biodigital Architecture]. In: Computation: The new realm of architectural design. Istanbul, 2009, pp. 681-686. (In Engl.)

21. Logvinov V.N. Priroda i arkhitektura. Put' integratsii integracii [Nature and architecture. Integration path]. Moscow, 2019, $218 \mathrm{p}$.

Прокофьева Екатерина Юрьевна (Москва). Кандидат архитектуры. Заведующий кафедрой «Ландшафтная архитектура» ФГБОУ В0 «Московский архитектурный институт (государственная академия) (107031, Москва, улица Рождественка, дом 11/4. МАРХИ). Эл. почта: plant-arc@mail.ru.

Лабезная Александра Вадимовна (Москва). Аспирант кафедры «Ландшафтная архитектура» ФГБОУ В0 «Московский архитектурный институт (государственная академия) (107031, Москва, улица Рождественка, дом 11/4. MАРХИ). Эл. почта: sasha1243@list.ru.

Prokofyeva Ekaterina Yu. (Moscow). Candidate of Architecture. Head of the Department of Landscape architecture of the Moscow Institute of Architecture (11/4 Rozhdestvenka st, Moscow, 107031. MARKHI).E-mail: plant-arc@mail.ru.

Labeznaya Alexandra V. (Moscow). Postgraduate student, the Department of Landscape architecture of the Moscow Institute of Architecture (11/4 Rozhdestvenka st., Moscow, 107031. MARKHI). E-mail: sasha1243@list.ru. 